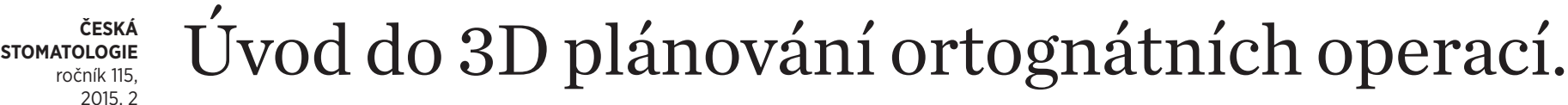 3D simulace ortognátní operace v programu Dolphin Imaging 3D ${ }^{\circledR}$
}

(Přehledový článek)

\section{Introduction to 3D Planning in Orthognatic Surgery. 3D Simulation of Orthognatic Surgery Using Dolphin Imaging $3 \mathrm{D}^{\circledR}$ Software}

(Review Article)

\section{ŠrubaY̌ M.', Dostálová T.', Hofimanová P. ${ }^{1}$, Foltán $R_{.}^{2}$, Eliášová H. ${ }^{3}$}

'Stomatologická klinika dětí a dospělých 2. LF UK a FN Motol, Praha

2Stomatologická klinika 1. LF UK a VFN, Praha

${ }^{3}$ Kriminalistický ústav, Praha

\section{SOUHRN}

Předmět sdělení: $V$ posledních letech dochází k rozvoji a pronikání 3D technologií do mnoha medicínských oborů. Stomatologie, ortodoncie a čelistní chirurgie nejsou výjimkou. Prověřené metody plánování ortognátních operací, jako jsou operace na sádrových modelech či 2D simulace, jsou považovány za „zlatý standard“ a vedou k osvědčeným výsledkům. Ovšem i tyto metody mají své hranice a omezení. Trojrozměrné (3D) prostředí přináší do plánování další, třetí rozměr, čímž se obraz přibližuje reálnému světu. To nám rozšiřuje možnosti např. při diagnostice některých asymetrií a umožňuje přesnější plánování ortognátních operací.

Využívá přitom moderních 3D zobrazovacích metod, jako jsou Cone Beam CT, stereofotogrammetrie či digitální modely zubních oblouků. Vzájemnou registrací (překrytím) zhotovených 3D snímků (3D modelů) vznikne virtuální 3D model pacienta. Tento model dokonale zobrazuje obličejový skelet (Cone Beam $\mathrm{CT}$ ), měkké tkáně obličeje (stereofotogrammetrický snímek) a zubní oblouky (digitální modely), někdy také označovaný jako tzv. triáda. Ve specializovaných počítačových programech, jako je např. Dolphin Imaging 3D $11.7^{\otimes}$ (Dolphin Imaging, Chatsworth, USA), provedeme na tomto virtuálním modelu 3D simulaci ortognátní operace.

Cílem tohoto článku je prezentovat tuto relativně novou metodu plánování ortognátních operací a zároveň i 3D zobrazovací metody, které jsou k 3D plánování využívány a dále popsat jednotlivé kroky při vlastní 3D simulaci ortognátní operace v počítačovém programu Dolphin Imaging 3D ${ }^{\circledR}$.

Klíčová slova: ortognátní chirurgie - ortodoncie - 3D simulace - Cone Beam CT - obličejový sken - digitální ortodontické modely

\section{SUMMARY}

AIM: Recently there has been a great progress in three-dimensional (3D) technologies in field of medicine. Dentistry and maxillofacial surgery haven't been exceptions. Methods such as model surgery or cephalometric methods of prediction (2D prediction) including video imaging are considered as "gold standards" in orthognathic surgery. However, these techniques, despite being routine part of the diagnosis and treatment planning process, have their limitations. 3D environment adds the third dimension to planning, which moves planning closer to reality and gives us more information for diagnosing a wider range of 
dentofacial anomalies. Furthermore, 3D planning increases accuracy of overall orthognatic planning by using modern 3D imaging methods, such as Cone Beam CT, stereophotogrammetry or digital models of dental arches. By merging these 3D images is created virtual model of patient head, described by some authors as triad.

It depicts facial skeleton (Cone Beam CT), facial soft tissues (stereophotogrammetry scan) and dental arches (digital models) in the most suitable way. The next step is to perform 3D simulation on this virtual model by using a planning software, e.g. Dolphin imaging 3D ${ }^{\circledR}$.

The aim of this article is to present relatively new method of orthognatic surgery planning and brings some information about 3D imaging technologies, which are essential as part of that process. Simultaneously fundamental steps (procedures) in orthognatic surgery 3D simulation using program Dolphin Imaging 3D ${ }^{\circledR}$ process are described.

\section{Keywords: orthognatic surgery, orthodontics - Cone-Beam Computed Tomography - facial scan - digital} dental models/casts

\section{ÚVOD}

Ortognátní operací korigujeme vzájemně nepříznivé postavení horní a dolní čelisti. Cílem je dosažení nového, výhodného postavení obličejového skeletu s ohledem na co nejlepší estetiku a harmonii obličeje, vyrovnání okluzních vztahů, a pokud možno i zlepšení objemových parametrů horních cest dýchacích.

Pomocí následného ortodontického pooperačního doléčení se snažíme docílit kvalitně fungujícího chrupu a stabilní artikulace zubů. Jde tedy o komplexní ortodonticko-chirurgickou léčbu vyžadující spolupráci ortodontisty a čelistního chirurga. K dosažení optimálního výsledku celé léčby je zapotřebí jejich úzké spolupráce, především pak při plánování ortodontického předléčení a vlastní ortognátní operace.

Tradičně se k tomuto plánování využívá tzv. modelové operace. Je to metoda, př̀i které se čelistní chirurg (zubní technik) snaží manuálně, vzájemnými posuny na sádrových modelech zasazených do artikulátoru, dosáhnout co nejlepší a nejstabilnější artikulace. Dlouhodobě je již považována za standardní postup [16]. Nedokonalost této metody však spočívá $\mathrm{v}$ tom, že neumožňuje chirurgovi vyhodnotit, v jaké míre plánovaný pooperační vztah zubních oblouků ovlivní morfologii přilehlých tvrdých a měkkých tkání obličeje [16]. Jinými slovy, máme dokonalý přehled o tom, jak budou zubní oblouky po operaci vzájemně artikulovat, ale nedává nám to žádnou představu o změně vzhledu pacienta po léčbě.

Metoda, která tento nedostatek částečně vyřešila, je tzv. 2D simulace (modelace). Ta funguje na principu vzájemného překrytí vyhodnoceného kefalometrického snímku a profilové fotografie pacienta. Je realizována ve specializovaném počítačo- vém programu určeném $\mathrm{k}$ ortodonticko-chirurgickému plánování. Vzhledem k tomu, že jsou oba snímky vzájemně registrovány (spojeny), posuny horní a dolní čelisti na kefalometrickém snímku (simulující posuny při ortognátní operaci) jsou přenášeny i na změny měkkých tkání, které reprezentuje profilová fotografie. Program tak dokáže na základě těchto posunů vyhodnotit a podle různých matematických modelů s velkou pravděpodobností vypočítat změny, ke kterým dojde na měkkých tkáních obličeje [22]. Tato metoda je však omezena na simulaci operace $z$ profilu obličeje pacienta, tedy $\mathrm{v}$ dvojrozměrném (2D) prostředí.

Neumožňuje pacientovi posoudit změnu estetiky tak, jak je zvyklý ji vnímat on sám, tedy při pohledu zepředu nebo z poloprofilu [5]. Navíc sama o sobě neumožňuje naplánovat stabilní pooperační vztah zubních oblouků při maximální interkuspidaci, a proto je ke kvalitnímu plánování nutné provést zároveň i modelovou operaci.

2D plánování ani modelová operace rovněž nedokážou identifikovat řadu dosti častých skeletálních asymetrií v transverzální rovině, např. laterogenii dolní čelisti. Dále 2D plánování neumožňuje chirurgovi úplně přesně rozeznat úskalí chirurgické korekce těchto transverzálních diskrepancí, které někdy mohou vést peroperačně $k$ nutnosti modifikace operační techniky nebo k provedení přídatných osteotomií [8].

Snahou by proto mělo být vyvinout spolehlivou metodu, která by umožnila co nejvěrněji plánovat ortognátní operace ve všech třech rovinách.

Jako nejvíce výhodné se nabízí plánování ortognátních operací v 3D prostředí, pomocí dnes již poměrně dostupných a neinvazivních $3 \mathrm{D}$ zobrazovacích metod. a.s. 
Plooij a kol.ve své studii uvádějí jako nejvhodnější pro simulaci ortognátních operací kombinované využití Cone Beam CT skenu, stereofotogrammetrických snímků obličeje (3D fotografie obličeje) a digitálních zubních modelů [20].

Spojením těchto 3D snímků (3D modelů) vznikne virtuální model pacienta, který označujeme jako tzv. triádu [20]. Virtuální model pacienta (triáda) pak pomocí takto spojených dat nejlépe zobrazuje pacientovy zubní oblouky (digitální modely), obličejový skelet (Cone Beam CT nebo CT) a měkké tkáně obličeje (3D fotografie).

\section{METODY}

\section{Cone Beam Computed Tomography (CBCT)}

Od doby, kdy byl poprvé v roce 1982 proveden na klinice Mayo první Cone Beam CT sken, došlo během několika desetiletí $\mathrm{k}$ jeho postupnému zavedení do běžné stomatologické a maxilofaciální praxe. V porovnání s konvenčním spirálním $\mathrm{CT}$ je to poměrně levná metoda s nesrovnatelně nižší radiační zátěží pro pacienta. Zároveň díky kvalitnímu zobrazení tvrdých tkání a krátké době snímání je tak CBCT téměř předurčeno k využívání v oblasti maxilofaciální chirurgie.

Doba snímání Cone Beam CT skenu by měla být co nejkratší kvůli eliminaci rizika pohybových artefaktů [9]. Tato doba se liší v závislosti na použitém protokolu snímání. Ten je stanoven hlavně indikací a také na základě požadované velikosti snímané oblasti, označované jako FOV (field of view). Dalším parametrem je rozlišení skenu, které určuje kvalitu snímku. Rozlišení je definováno velikostí voxelu, což je základní jednotka trojrozměrného snímku tvaru krychle o různé velikosti (většinou 0,125-0,400 mm). Každý výrobce Cone Beam CT přístrojů uvádí doporučené protokoly v závislosti na velikosti snímané oblasti (FOV), rozlišení skenu a době snímání.

Pro účely plánování ortognátní operace je zapotřebí snímek s velkým rozsahem zobrazených tvrdých a měkkých tkání obličeje. Mluvíme pak o rozšířeném poli snímání (EFOV - extended field of view). S ohledem na velikost FOV a s ne velmi extendovanými požadavky na přesnost operace a plánování, je doporučena větší velikost voxelu - 0,300 mm.

Pro potřeby plánování operace je to dostatečně velké rozlišení a při rozširrené velikosti snímaného pole je tímto snížena radiační zátěž a celková doba snímání. Kratší doba snímání s menším počtem základních snímků vede ke snížení rizika vzniku pohybových artefaktů. Také objem dat takto velkého CT skenu by byl, při zachování standardního rozliše- ní, příliš náročný na další zpracování v plánovacích počítačových programech.

Efektivní dávka pro rozšířené pole snímání (EFOV) s adekvátní velikostí voxelu $(0,300$ či 0,400 $\mathrm{mm}$ ) se liší v závislosti na vlastnostech použitého tomografu. Na naší klinice používaný tomograf i-CAT The Next Ceneration (Imaging Sciences Inter. , LLC, Hartfield, USA), při protokolu FOV $-23 \times 17 \mathrm{~cm}$, velikosti voxelu - 0,300 mm, napětí $120 \mathrm{kV}$, proudu $5 \mathrm{~mA}$ a době snímání 3,7 sekundy, má efektivní dávku uváděnou výrobcem 0,069 mSv (ICRP, 2007). Ve srovnání s panoramatickým snímkem, kde se podle studie Ludlowa a kol. [14] pohybuje efektivní dávka v rozmezí 0,014-0,024 mSv, je to ale stále několikanásobně větší dávka.

Většina výrobců Cone Beam CT přístrojů se v dnešní době doslova předhání ve snaze o dosažení co nejnižších efektivních dávek, při zachování dostatečně kvalitního zobrazení, takže můžeme očekávat pokračující trend ve snižování radiační zátěže.

Ludlow a kol. ve své nejnovější studii zkoumali přístroj I-CAT FLX ${ }^{\circledR}$ (Imaging Sciences International, Hatfield, USA) a naměřili u protokolů Quick/Quick+ hodnoty v rozmezí $0,011-0,0120 \mathrm{mSv}$. Tyto protokoly jsou primárně určeny pro snímání dětí a vykazují v závislosti na velikosti FOV (horní nebo dolní čelist) i nižší hodnoty než pro panoramatické snímky. V závěru studie bylo také zhodnoceno, že kvalita skenu je stále dostatečná pro diagnostické účely [15].

Podle odhadů (NCRP, 2006) průměrný člověk v USA absorbuje ročně efektivní dávku okolo 3,1 mSv z přirozeně se vyskytujících radioaktivních zdrojů a kosmického záření. Ve Velké Británii asi kolem 2,7 mSv (SEDENTEXCT). Tato hodnota se liší i v závislosti na lokalitě (nadmořská výška, přímořské oblasti) [20, 23]. Pro zajímavost, při letu z New Yorku do Tokya a zpět, mưže přepravovaná osoba absorbovat efektivní dávku až 0,2 mSv.

Většina autorů upřednostňuje pořizování Cone Beam CT snímku v sedící pozici pacienta (např. i CAT) před přístroji, které snímají pacienta v ležící pozici $[5,17,18]$. Jako logický argument se uvádí vliv gravitační síly na rozdílné prostorové rozložení měkkých tkání obličeje při snímání vsedě (CBCT) a vleže, kdy se pacient méně pohybuje (spirální CT ) $[5,18]$.

\section{Stereofotogrammetrie (3D fotografie)}

Stereofotogrammetrie je zobrazovací metoda založená na snímání daného objektu dvěma kamerami umístěnými od sebe v určité vzdálenosti, fungujícími na podobném principu jako lidský zrak [9].

Poprvé byla jako zobrazovací metoda doporučena pro použití v zubním lékařství Mannsbachem již $\mathrm{v}$ roce 1922 [18]. 
Stereofotogrammetrický skener pomocí matematického triangulačního algoritmu dokáže identifikovat a spojit pořízené snímky daného objektu, a vypočítat tak jeho třetí rozměr - hloubku obrazu.

Na senzoru prýstroje jsou zaznamenány informace o poloze snímaných bodů. Každý bod má souřadnice na ose $\mathrm{x}$, y a $\mathrm{z}$. Těchto bodů (koordinátů) je snímáno několik tisíc až desítek tisíc. Vytvoří obrovskou množinu bodů nazývanou mračno bodů (point-cloud). Toto mračno bodů reflektuje svým uspořádáním prostorovou strukturu snímaného objektu a je nositelem informace o prostorové struktuře objektu. Dává základ pro vytvoření geometrie 3D obrazu modelu.

Jakmile je vytvořena geometrie modelu, program připojí barevnou texturu, která dodává modelu fotorealistické zobrazení [13]. Vznikne tak přesný fotorealistický 3D model objektu, v našem př́ípadě tváře pacienta. Důležitá je kalibrace přístroje před vlastním snímáním, tak aby byla skenerem zaznamenána skutečná vzdálenost senzorů od objektu, a program tak mohl přesně vypočítat 3D strukturu objektu.

Důvod pro zapojení 3D fotografie obličeje do procesu plánování ortognátních operací je ten, že vlastní segmentací Cone Beam CT snímku jsme sice schopni vytvořit povrch zobrazující měkké tkáně obličeje, ne však v požadované kvalitě a vhodném fotorealistickém zobrazení [5]. Absence polychromatického zobrazení Cone Beam CT skenu, tzn. živosti měkkých tkání, znamená, že vypadá spíše jako mrtvolná maska než obličej pacienta, a tudíž postrádá informace, které jsou důležité při fotorealistickém vnímání lidského obličeje.

Ayoub již ve své práci z roku 2007 zmiňuje použití stereofotogrammetrického skeneru jako nejslibnější metodu snímání tváře pro potřebu 3D plánování [5]. Výhody stereofotogrammetrických skenerů jsou především ve velkém rozsahu snímané plochy a rychlosti jejich pořízení. Moderní skenery jsou schopny snímat objekt v úhlu 180 stupňư, a pokrýt tak celý povrch obličeje v rozsahu nutném k simulaci ortognátní operace [10].

Doba expozice u moderních optických stereofotogrammetrických skenerů je v řádu milisekund, takže zde riziko pohybových artefaktů významně nehrozí.

Kupříkladu námi používaný skener Vectra $M 3^{\circledR}$ (Canfield, USA) má dobu expozice uváděnou výrobcem přibližně 3,5 milisekundy. Ideálně by doba vlastního snímání měla proběhnout do čtyř milisekund, dostatečně rychle pro minimalizaci pohybu a získání kvalitního snímku [13].
Důležité je také správné nastavení, kalibrace a poučení pacienta zaškoleným pracovníkem. Především je nutné zdůraznit význam neutrálního výrazu tvářové mimiky během snímání. Mělo by být neutrální a pro eliminaci vertikálních odchylek by měl mít pacient skousnuto v maximální interkuspidaci nebo centrální okluzi, rty jsou v klidové pozici, tzn. bez tonusu [10].

Mezi nejčastěji používané stereofotogrammetrické skenery patří Vectra $M 3^{\circledR}$ (Canfield, Fairfield, USA), 3dMD ${ }^{\circledR}$ (3dMD, Atlanta, USA) a Di3D ${ }^{\circledR}$ (Dimensional Imaging, Glasgow, Anglie).

\section{Digitální modely}

Důležitost digitálního modelu při plánování ortognátní operace vysvětluje př́tomnost kovových artefaktů (ortodontické kroužky, zámky, př́idatná ortodontická zařízení, amalgámové výplně, protetika). Rovněž v př́ípadě, kdy nepoužijeme okluzní šablony při pořizování Cone Beam CT snímku, se zubní oblouky zobrazí jako jednolitý objem s nemožností identifikace okluze, a to ani při pečlivé segmentaci zubní tkáně. Na Cone Beam CT je vzhledem k beam hardening např. řezák až o $1 \mathrm{~mm}$ větší než ve skutečnosti [19]. Dalším argumentem je lepší kvalita zobrazení a rozlišení digitálních modelů. $V$ př́ípadě Cone Beam CT je to v důsledku volby většího rozlišení při skenování otisků nebo modelů v porovnání s původním 3D snímkem pacienta. Použití digitálních modelů zlepšuje požadovanou postoperační artikulaci, a tím i korektní polohování horní a dolní čelisti při 3D plánování ortognátní operace [19]. Digitální zubní modely můžeme získat skenováním již odlitých sádrových modelů, zubních otisků či přímým skenováním.

V prvních dvou případech se modely či otisky skenují pomocí optických laboratorních skenerů nebo na Cone Beam CT. Přímé skenování je založeno na snímání zubních oblouků intraorálním skenerem v ústech pacienta. Použití Cone Beam CT či laboratorních skenerů jsou spolehlivé metody při výrobě digitálních modelů v klinické praxi $[4,6,11,21,24$, 25]. Intraorální skenery jsou v tomto ohledu méně jednoznačné $[3,6,7]$. Crünheid a kol. ve své poslední studii hodnotí tuto metodu jako spolehlivou, avšak vzhledem k malému souboru je i nadále potřeba dalších studií. Zároveň konstatují, že tato metoda je poměrně časově náročná ve srovnání s konvenčním otiskováním [7].

Pokud jsou však během léčby použity ortodontické zámky a kroužky, které způsobují deformaci standardně používaných otiskovacích hmot, logicky se v tomto prípadě jeví použití intraorálních skenerů jako metoda volby. Zatím však chybí po-

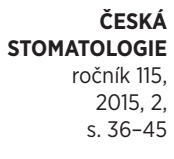


třebné klinické zkušenosti a podrobnější informace v literatuře.

\section{Překrytí CBCT skenu s obličejovou 3D fotografií}

Jak již bylo řečeno, existuje několik důvodů pro překrývání 3D fotografie obličeje s Cone Beam CT snímkem. Především je to kompenzace nepřesností Cone Beam CT při segmentaci povrchu měkkých tkání a dodání 3D modelu fotorealistického vzhledu $[5,10,17]$. Nicméně při překrývání Cone Beam CT skenu s 3D fotografií mohou rozdíly ve výrazu (expresi) tvářové mimiky a jiné rozložení měkkých tkání, vlivem odlišné polohy při snímání, snížit přesnost překrytí [17]. Při zhotovení klasického spirálního CT je pacient snímán v ležící pozici, naopak při snímání 3D fotografie (streofotogrammetrického snímku) a většiny Cone Beam CT přístrojů je pacient v sedící nebo stojící pozici.

Ve studiích, kde byly k vzájemné registraci použity snímky z konvenčního CT a 3D obličejové fotografie, byly naměřeny větší rozdíly v přesnosti překrytí než při překrývání 3D fotografie s Cone Beam CT skenem, což se dává do souvislosti s rozdílnou polohou při snímání $[5,18]$. Abychom získali co nejpřesnější superimpozici, jinými slovy, aby se 3D fotografie a Cone Beam CT snímek co nejlépe překrývaly, doporučují někteří autoři co nejkratší interval mezi pořízením obou snímků.

Ideálně by pak snímání mělo probíhat současně, jako je to u přístroje Planmeca 3D ProMax + ProFace (Planmeca Inc., Roselle, IL, USA) [17, 18]. Ayoub a kol. ve své studii za podmínek, kdy byly skeny pořízeny samostatně, uvádějí průměrnou odchylku při překrytí Cone Beam CT a 3D obličejového skenu v rozmezí $\pm 1,5 \mathrm{~mm}$ [5]. Podle studie Naudiho a kol. [17] byly u měřených bodů nepřesnosti po překrytí v rozmezí 0,3-0,9 mm u snímků zhotovených jednotlivě (rozmezí pořízení do jedné hodiny). U snímků pořízených současně byla chyba překrytí menší, a to 0,4 mm a méně.

Současným zhotovením obou snímků značně eliminujeme rozdíly ve výrazu tvářové mimiky během snímání, která má výrazný podíl na přesnosti či nepřesnosti a může být značně rozdílná i během jednoho dne (vyjadřuje nálady a pocity pacienta během vyšetření). Přispívá tak ke kumulaci chyb při dalším měření $[5,17]$.

V našich podmínkách však zatím v praxi narážíme na vysokou pořizovací cenu jednotlivých zařízení. Je tak téměř nemožné vybavit jedno pracoviště veškerým potřebným sortimentem tak, abychom byli schopni minimalizovat tyto chyby při snímání. Proto se musíme prozatím spokojit se spoluprací mezi jednotlivými pracovišti a sna- hou o co nejkratší interval mezi pořizováním snímků.

\section{Vytvoření 3D simulace ortognátní operace v pro- gramu Dolphin Imaging 3D ${ }^{\circledR}$, verze 11.7 beta}

Po získání potřebných dat, tzn. po zhotovení Cone Beam CT skenu o požadované velikosti FOV, obličejové 3D fotografie (stereofotogrammetrického snímku) a digitálních modelů zubních oblouků, můžeme přistoupit k vlastní 3D simulaci ortognátní operace.

Mezi nejznámější počítačové programy určené k 3D plánování patří Dolphin Imaging $3 \mathrm{D}^{\circledR}$ (Dolphin Imaging, Chatsworth, USA), SimPlant

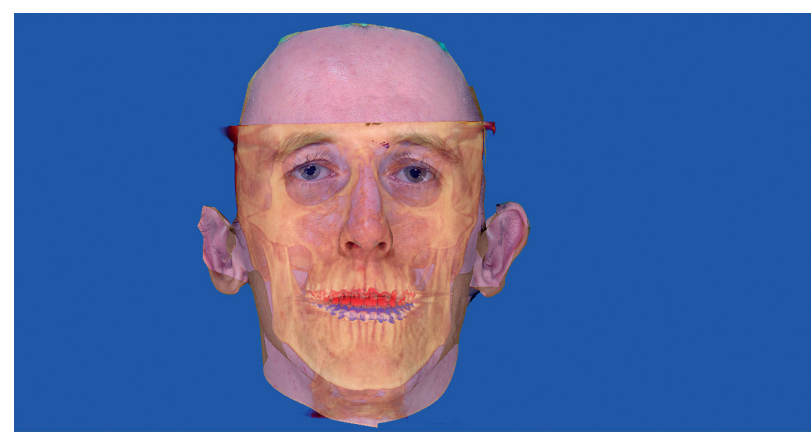

Obr. 1a Triáda

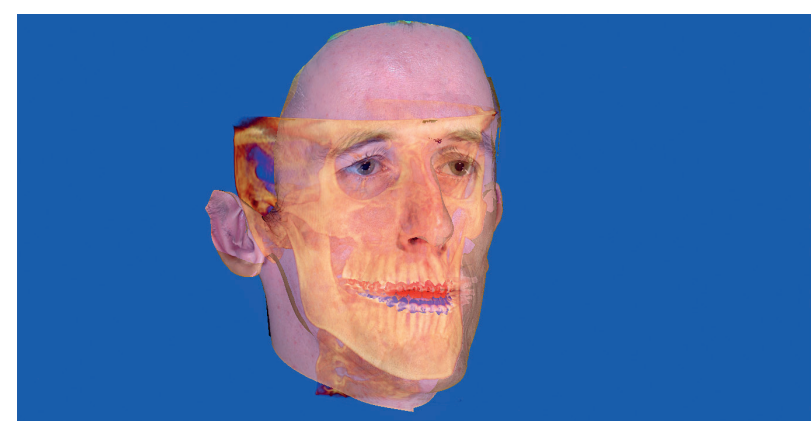

Obr. 1b Triáda

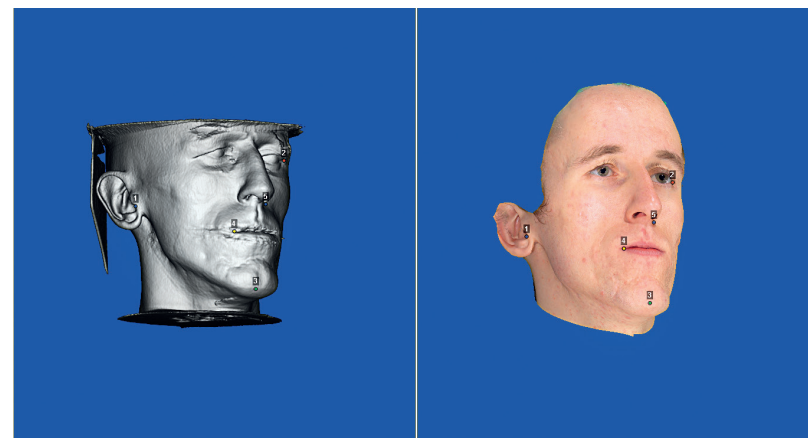

Obr. 2 Vzájemná registrace Cone Beam CT a 3D fotografie podle nadefinovaných bodů 
$\mathrm{O \& O}^{\circledR}$ (Materialise, Leuven, Belgie), NemoCeph 3D ${ }^{\circledR}$ (Nemotec, Madrid) a Maxilim ${ }^{\circledR}$ ( Medicim, Mechelen, Belgie).

Námi používaný program Dolphin Imaging 3D ${ }^{\circledR}$ verze 11.7 beta, je komplexní software, určený nejen pro ukládání fotografií a analýzu kefalometrického snímku v běžné ortodontické praxi, ale také pro kombinovanou ortodonticko-chirurgickou léčbu zahrnující 2D a 3D plánování ortognátních operací.

Než zahájíme proces vlastního 3D plánování, je nejprve potřeba importovat do programu Dolphin Imaging $3 \mathrm{D}^{\circledR}$ příslušný Cone Beam CT sken pacienta, následně pak 3D fotografii a digitální modely. Jejich

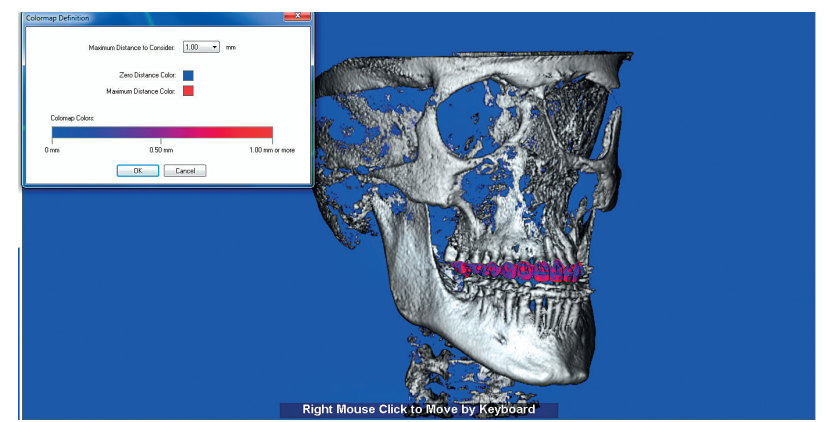

Obr. 3a Barevná mapa (histogram) - můžeme měnit rozsah stupnice $(\mathrm{v} \mathrm{mm})$

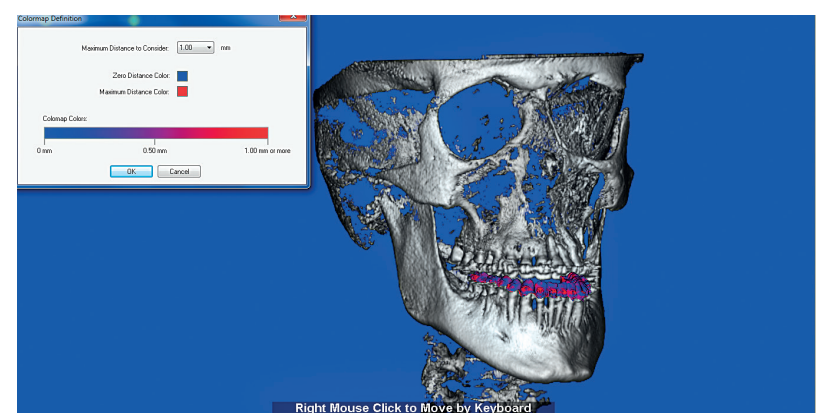

Obr. 3b Barevná mapa (histogram) - můžeme měnit rozsah stupnice ( $v \mathrm{~mm}$ )

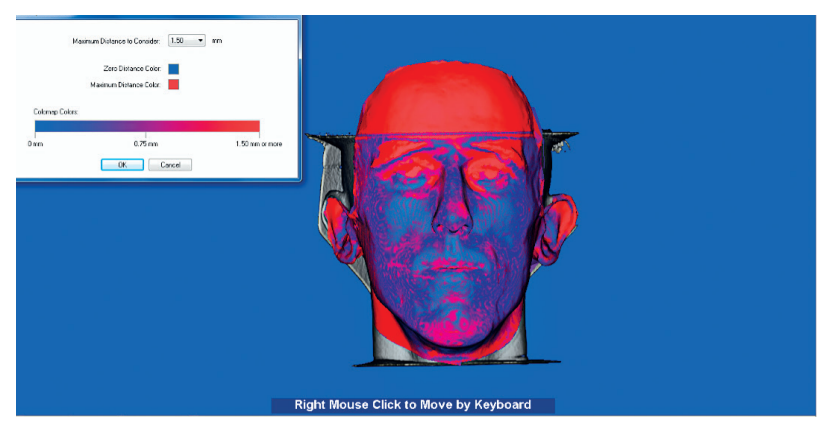

Obr. 3c Barevná mapa (histogram) - můžeme měnit rozsah stupnice $(\mathrm{v} \mathrm{mm})$ vzájemným překrytím vytvoříme 3D virtuální model pacienta - triádu [20] (obr. 1a, b).

Vzájemná registrace 3D snímků (modelů) je v tomto programu založena na principu dvoufázové registrace. V první fázi vytvoříme „hrubé překrytí“, jež je založeno na registraci pomocí nadefinovaných bodư (point based registration). Je zapotřebí vhodně umístit tř̀i až pět přibližně souhlasných bodư na povrchu obou skenů a následně provést jejich překrytí (obr. 2). Cílem tohoto procesu je oba modely vzájemně těsně přiblížit a vhodně prostorově nastavit [12].

Poté program Dolphin 3D pomocí funkce autosuperimpozice co nejpřesněji oba snímky spojí. Využívá přitom složitého matematického ICP (Iterative Closest Point) algoritmu, určeného k překrývání dvou téměř identických 3D povrchů (surface based registration).

Přesnost překrytí můžeme kvalitativně verifikovat barevným histogramem ve formě mapy (color map), která pomocí barevné škály (uváděna $\mathrm{v}$ milimetrech) zobrazuje velikost odchylky při překrytí dvou 3D modelů (snímků) (obr. 3a, b, c) .

Vzájemně registrované snímky poté upravíme, a to odstraněním nepotřebných dat na 3D fotografii obličeje (obr. 4). Zbavujeme se především oblastí, které jsou pro samotnou simulaci nepotřebné. Vlasatou část hlavy jsme již eliminovali během vlastního pořizování 3D fotografie, protože z hlediska plánování komplikují vlasy a jiné tenké, dobře reflexní objekty obličejovou diagnostiku, analýzu a samotný výsledek simulace [13].

Dalším krokem je již samotný proces simulace vytvořeného 3D modelu (triády).

Z Cone Beam CT skenu nejprve generujeme OPC snímek. Na něm definujeme budoucí segmenty horní a dolní čelisti (obr. 5).

Tyto segmenty dále upravíme v 3D rekonstrukci. Odříznutím (čištěním) segmentů od zbytku 3D rekonstruovaného obrazu (Cone Beam CT skenu), které nejsou důležité pro simulaci, získáme lepší přehled o struktuře jednotlivých segmentů (obr. 6).

Na takto připravených segmentech čelistních kostí chirurg provede zamýšlené virtuální osteotomie. Osteotomie (řezy kostí) provádí chirurg podle typu indikované operace. V horní čelisti zpravidla provádíme osteotomii typu Le Fort I (obr. 7) jako jeden segment, někdy ve třech segmentech doplněné alveolotomií premaxily, $v$ dolní čelisti pak BSSO (bilateral sagital split osteotomy). Doplňkově někdy i osteotomii pro realizaci genioplastiky (estetické úprava bradového výběžku).

Po provedení indikovaných osteotomií následuje 3D analýza tvrdých a měkkých tkání (obr. 8, 9). 
Šrubař M., Dostálová T., Hofmanová P., Foltán R., Eliášová H.

ČESKÁ

STOMATOLOGIE

ročník 115 ,

2015, 2,
Nyní je virtuální model připravený k vlastní simulaci ortognátní operace. Ta je prováděna podobně jako při modelové operaci, kdy se snažíme o dosažení co nejstabilnějšího vztahu zubních oblouků. K dispozici je několik nástrojů sloužících ke kontrole výsledného vztahu. Jedním z nich je kolizní mapa, která udává, kde a o kolik (v milimetrech), dochází k překrývání zubních oblouků ve vertikálním rozměru (crossingu). Pokud se na některých místech zubní oblouky navzájem překrývají (červená barva), je třeba vytvořit nový vztah. Jinak by nebylo možné vytvořit stabilní okluzi bez zábrusů zubů na operačním sále.

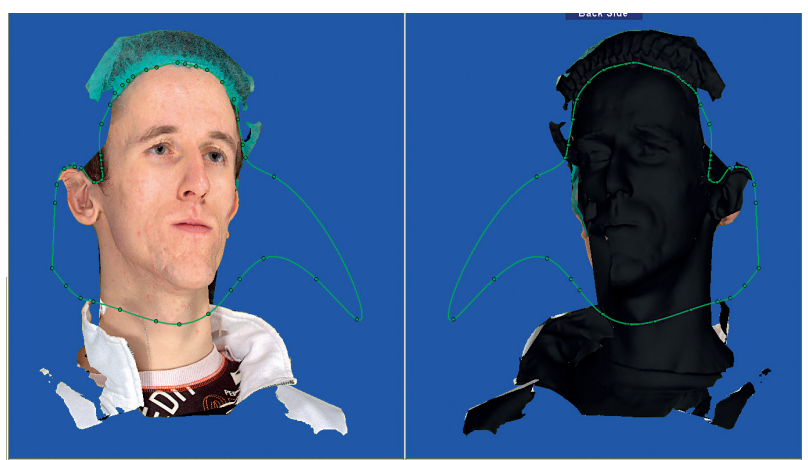

Obr. 4 Odstranění nepotřebných dat

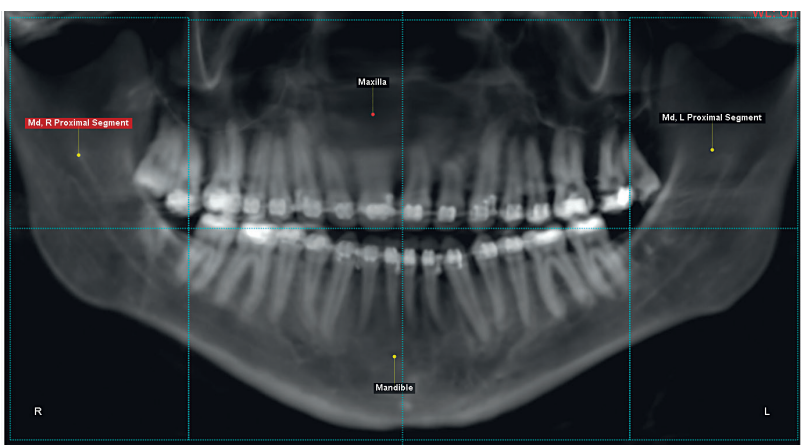

Obr. 5 OPG generované z CBCT skenu s rozvržením segmentů

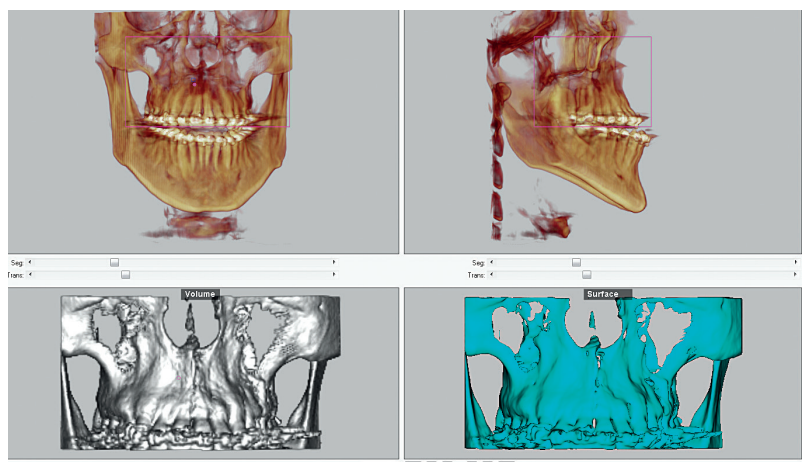

Obr. 6 Vytvoření segmentů v 3D rekonstrukci
Pohyby kostních segmentů jsou programem okamžitě přepočítávány na měkké tkáně obličeje, takže můžeme posoudit, jaký vliv bude mít jednotlivý posun segmentu na estetiku obličeje (obr. 10).

Je možné provádět měření ve všech rovinách, a tak například i vypočítat či ověřit posuny, které jsou nutné ke korekci asymetrií obličeje.

Součástí je i pracovní list, kde máme přehled o všech změnách od výchozí pozice až po poslední provedený posun.

Na závěr simulace, kdy jsme dosáhli vyhovujícího vztahu zubních oblouků a zároveň i estetiky obličeje, je jako výstup celého procesu simulace ortognátní

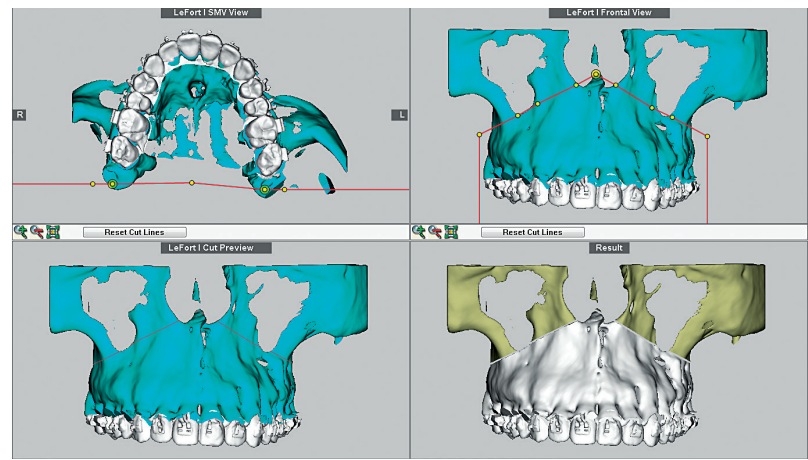

Obr. 7 Osteotomie - LeFort I

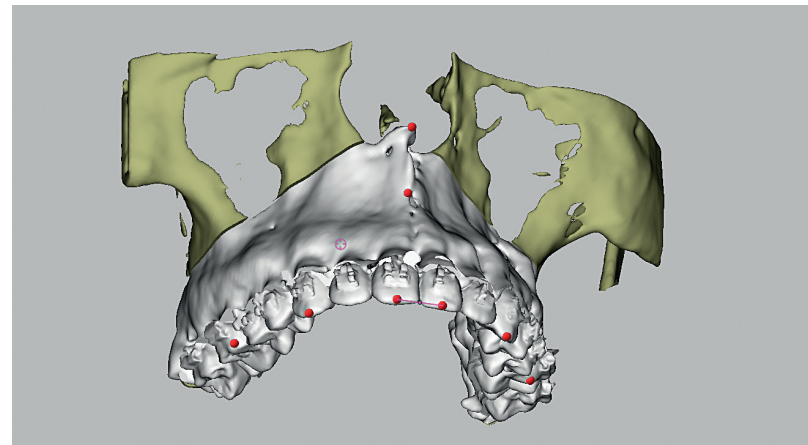

Obr. 8 3D analýza tvrdých a měkkých tkání

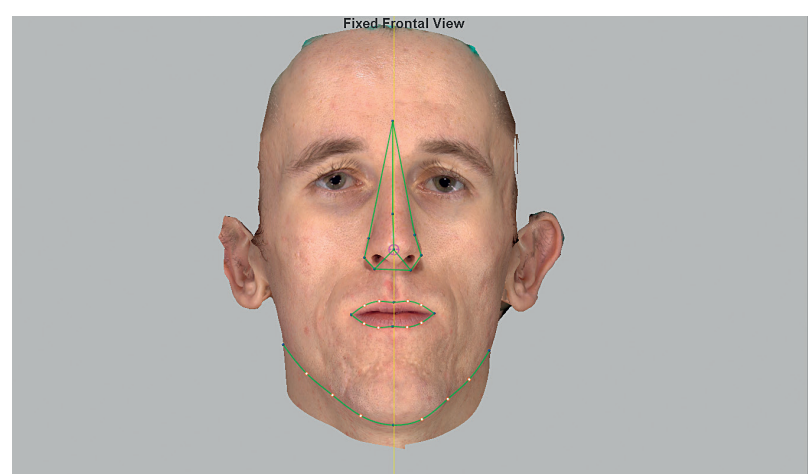

Obr. 9 3D analýza tvrdých a měkkých tkání 
operace programem navržena operační a pooperační digitální dlaha (splint) (obr. 11). Ta slouží během operace ke správnému trojrozměrnému umístění uvolněného segmentu čelistí, který se dočasně fixuje pomocí okluze k pevné druhé čelisti, a tím umístí již osteomovanou čelist do požadované pozice, kde je fixována osteosyntetickým materiálem. Pokud se operuje na obou čelistech současně, pak se stejný postup, ale s druhou pooperační dlahou, opakuje. Ta pak může sloužit i šest týdnů po operaci v hojícím období ke stabilizaci pooperační okluze - takže pacient ji stále používá.

Tuto dlahu je možné exportovat v STL formátu, a následně pak vyrobit pomocí 3D tisku. Pokud máme $\mathrm{k}$ dispozici dostatečně kvalitní 3D tiskárnu, která zároveň dokáže tisknout z certifikovaného biokompatibilního materiálu, je možné tuto dlahu využít při ortognátní operaci (obr. 12). Zvýšíme tak bezesporu přesnost 3D plánování a výslednou morfologii měkkých tkání obličeje.

Adolphs a kol. ve své pilotní studii porovnávali na malém souboru pacientů přesnost peroperačních splintů, vyrobených CAD/CAM metodou. Tyto dlahy byly navrženy počítačovým programem a následně vyrobeny pomocí 3D tiskárny. Srovnávají je s dlahami vyrobenými tradiční metodou, tzn. na sádrových modelech zastavěných v artikuláturu. Popisují, že dlahy vyrobené CAD/CAM metodou, byly plně ekvivalentní s těmi, které byly vyrobeny konvenční metodou na sádrových modelech [2].

\section{DISKUSE A ZÁVĚR}

Vlivem prudkého rozvoje 3D technologií v posledních několika letech dochází nevyhnutelně i ke snaze o jejich využití v oblasti stomatologie, ortodoncie a čelistní chirurgie.

Jednou z priorit výrobců dnešních Cone Beam CT př́istrojů je snižování radiační zátěže pacienta na co nejnižší efektivní dávky při současném zachování dostatečné kvality zobrazení. Jelikož při 3D pánování potřebujeme Cone Beam CT snímek o co největším poli zobrazení (EFOV), měli bychom dbát na co nejmenší radiační zátěž pacienta. Kvalita snímku je i při menším rozlišení pro potřeby 3D plánování stále dostatečná. Nezanedbatelné je také snižování objemu dat pro práci v počítačových simulačních programech. Pořízení Cone Beam CT snímku pro potřeby plánování ortognátní operace můžeme považovat za oprávněné a indikované (SEDENTEXCT, 2011) [23].

Pokud jde o obličejové skenery, obzvláště pak těch pracujících na principu stereofotogrammetrie, je kvalita zobrazení na velmi vysoké úrovni. Jeden z prvořadých cílů je v tomto ohledu zvýšení přesnosti sestavení virtuálního modelu díky současnému pořízení Cone Beam CT snímků s 3D fotografií, tak abychom eliminovali rozdíly v dynamických změnách a pohybech měkkých tkání obličeje během snímání.

V oblasti výroby digitálních modelů je již poměrně osvědčené skenování sádrových modelư laboratorními skenery. Ovšem nastupující využití optických intraorálních skenerů, určených k přímému skenování zubních obloukư a přilehlých tkání v ústech, se může stát jednodušší a rychlejší cestou $\mathrm{k}$ jejich zhotovení. Při klasickém postupu výroby sádrových modelů otiskujeme bud' pomocí alginátových otisko-

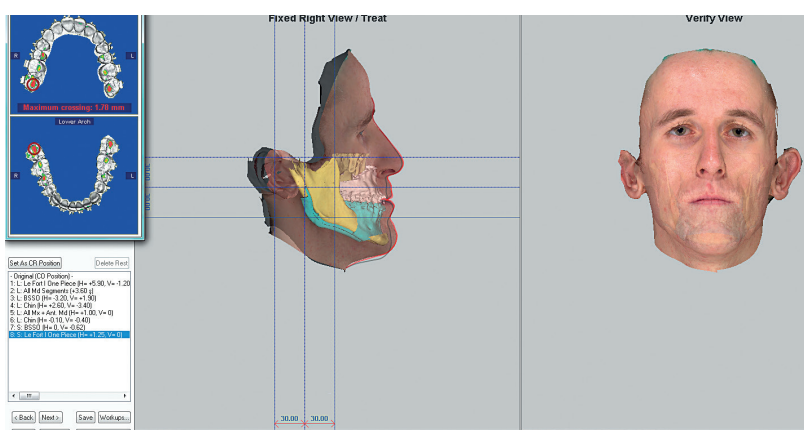

Obr. 10 Posuny jednotlivých segmentů, kontrola artikulace pomocí kolizní mapy

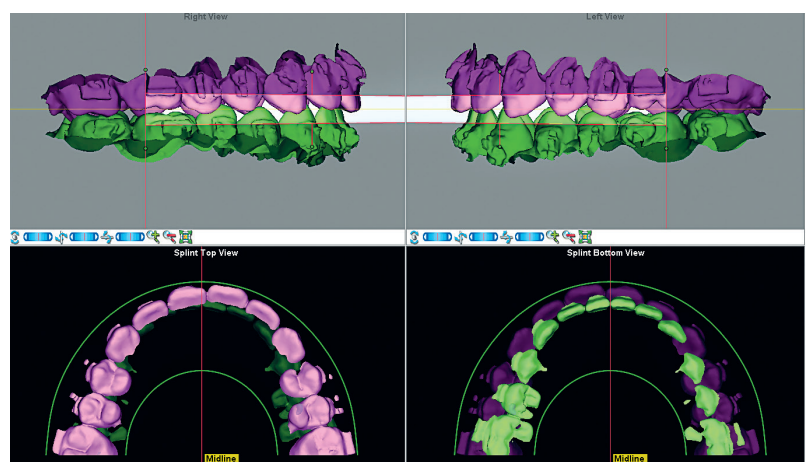

Obr. 11 Návrh peroperační okluzální dlahy

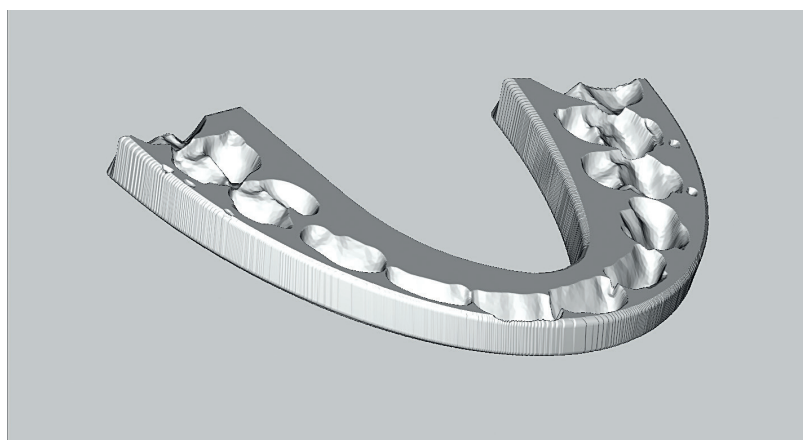

Obr. 12 Peroperační okluzální dlaha ve stereolitografické podobě 
vacích hmot, nebo, v lepším případě, hmot silikonových. Vlivem nalepených ortodontických zařízení na zubech (zámky, kroužky či oblouky) dochází ovšem $\mathrm{k}$ deformaci těchto otisků a nepřesnostem při jejich následném skenování nebo vylívání sádrou. Absence nutnosti otiskování při použití intraorálního skeneru by mohla tuto nevýhodu odstranit. Záleží však na tom, jak se intraorální skenery v budoucnu osvědčí při rutinním použití v praxi. Grünheid kol. ve své nejnovější studii (2014) popisují snímání použitým optickým intraorálním skenerem (Lava COS; 3M ESPE, St. Paul, Minnesota, USA) jako stále poměrně nekomfortní a časově náročné [7]. V budoucnu se dá očekávat technologický pokrok a postupné odstraňování těchto nevýhod.

Obecně v našich podmínkách stále narážíme na vysokou pořizovací cenu jednotlivých zařízení, tudíž je i prakticky nereálné koncentrovat veškeré potřebné vybavení na jednom pracovišti. Jsme proto leckdy odkázáni na spolupráci mezi jednotlivými institucemi, což zvyšuje nároky na koordinaci a kvalitu získávaných dat.

Pomineme-li vysokou pořizovací cenu jednotlivých 3D snímků a plánovacího programu, je 3D plánování oproti standardně využívané modelové operaci nebo 2D simulaci nesrovnatelně časově náročnější. Tato časová náročnost opět zvyšuje finanční náklady. Vzhledem $\mathrm{k}$ tomu, že u nás tento výkon není hrazen $z$ veřejného zdravotního pojištění, vyvolává to také otázku ohledně paušálního využití 3D simulace $v$ běžné praxi.

Zatím v literatuře nejsou k dispozici rozsáhlejší systematické studie týkající se přesnosti 3D plánování, proto je obtížné absolutní srovnání se standardně používanými postupy. Většinou se tak jedná o případové studie nebo malé soubory. Téměř všichni autoři se však zatím shodují, že 3D plánování může být považováno za minimálně stejně přesně, ne-li přesnější než konvenční metody.

Velkou otázkou také zatím zůstává, jak přesně budeme schopni pomocí 3D plánování simulovat výslednou estetiku měkkých tkání obličeje. Je to zatím asi nejvíce problematická stránka této nové metody. S přibývajícími studiemi a postupným zdokonalováním plánovacích programů se dá očekávat dosahování velké přesnosti. $V$ tomto případě asi nejvíce záleží na striktním dodržení co nejpřesnějšího postupu a nutnosti použití programem generované dlahy. Při tomto postupu přeneseme 3D virtuální plánování přímo na operační sál. Pak můžeme hodnotit samotnou přesnost programu $v$ tom, jak věrohodně dokáže přepočítat posuny kostního skeletu na posuny měkkých tkání s dopadem na výslednou estetiku a harmonii celého obličeje [1].
Prozatím nejsou v dostupné literatuře dostatečně validní data pro to, abychom byli schopni pacientovi „garantovat", jak se ortognátní operace projeví na tolik očekávané změně vzhledu obličeje. Tato skutečnost se může stát pro operatéra rizikovou záležitostí, pokud by pacient nebyl dostatečně informován o současných limitech 3D simulace.

$S$ přibývajícími zkušenostmi a validními studiemi lze předpokládat i postupný vývoj plánovacích programů, a tím i zdokonalování 3D simulace.

Odborníci v maxilofaciální chirurgii jsou přesvědčeni, že v 3D simulaci při realizaci ortognátních operací tkví velký potenciál a nebude již trvat dlouho, kdy bude využívána jako spolehlivý nástroj k jejich plánování.

\section{Zkratky a vysvětlivky}

ICRP - International Commission on Radiological Protection - nezávislá mezinárodní organizace podávající doporučení a návody týkající se radiační ochrany, vydává hodnoty pro tkáňový (orgánový) váhový faktor - $\mathrm{WT}$, jenž vyjadřuje relativní příspěvek daného orgánu nebo tkáně k celkové zdravotní újmě způsobené rovnoměrným ozářením těla [27].

FOV - field of view - velikost zobrazovaného pole snímaného objektu na Cone Beam CT skenu.

EFOV - extented fiel of view - rozšsiřcené pole snímání (např. 23×17 cm).

NCRP - National Council on Radiation Protection and Measurement - americká organizace zabývající se radiační ochranou v USA.

Point Based Registration - metoda, při které se překryjí dva 3D modely podle určitého počtu předem definovaných bodů.

Surface Based Registration - metoda překrývání dvou 3D modelů na základě jejich povrchové struktury (3D geometrie), používá při tom složité matematické algoritmy (např. ICP algoritmus).

ICP - Iterative closest point - matematický algoritmus využívaný $\mathrm{v}$ 3D grafice $\mathrm{k}$ překrývání dvou $3 \mathrm{D}$ modelů.

SEDENTEXCT - je celosvětový projekt spolupráce univerzit a odborníků, který má za cíl na základě vědeckých poznatků (evidence based medicine) stanovit doporučení při používání Cone Beam CT v medicíně.

\section{LITERATURA}

1. Aboul-Hosn Centenero, S., Hernández-Alfaro, F.: 3D planning in orthognathic surgery: CAD/CAM surgical splints and prediction of the soft and hard tissues results - our experience in 16 cases. J. Craniomaxillofac. Surg., roč. 40, 2012, č. 2, s. 162-168.

2. Adolphs, N., Liu, W., Keeve, E., Hoffmeister, B.: RapidSplint: virtual splint generation for orthognathic surgery - results 
of a pilot series. Comput. Aided. Surg., roč. 19, 2014, č. 1-3, s. $20-28$.

3. Akyalcin, S., Cozad, B. E., English, J. D., Colville, C. D., Laman, S.: Diagnostic accuracy of impression-free digital models. Am. J. Orthod. Dentofacial. Orthop., roč. 144, 2013, č. 6, s. 916-922.

4. Akyalcin, S., Dyer, D. J., English, J. D., Sar, C.: Comparison of 3-dimensional dental models from different sources: diagnostic accuracy and surface registration analysis. Am. J. Orthod. Dentofacial Orthop., roč. 144, Dec 2013, s. 831-837.

5. Ayoub, A. F., Xiao, Y., Khambay, B., Siebert, J. P., Hadley, D.: Towards building a photo-realistic virtual human face for craniomaxillofacial diagnosis and treatment planning Int. J. Oral Maxillofac. Surg., roč. 36, 2007, č. 5, s.423-428.

6. Flügge, T. V., Schlager, S., Nelson, K., Nahles, S., Metzger, M. C.: Precision of intraoral digital dental impressions with iTero and extraoral digitization with the iTero and a model scanner. Am. J. Orthod. Dentofacial Orthop., roč 144, 2013, č. 3, s. 471478.

7. Grünheid, T., McCarthy, S. D., Larson, B. E.: Clinical use of a direct chairside oral scanner: an assessment of accuracy, time, and patient acceptance. Am. J. Orthod. Dentofacial Orthop., roč. 146, 2014, č. 5, s. 673-682.

8. Grybauskas, S., Balciuniene, I., Vetra, J.: Validity and reproducibility of cephalometric measurements obtained from digital photographs of analogue headfilms. Stomatologija, roč. 9, 2007 s. 114-120.

9. Hanzelka, T.: Cone Beam CT ve stomatologii: Pohybové artefakty a jejich redukce. Disertační práce, 2013.

10. Heike, C. L., Upson, K., Stuhaug, E., Weinberg, S. M.: 3D digital stereophotogrammetry: a practical guide to facial image acquisition. Head Face Med., roč. 28, 2010, č. 6, s. 18.

11. Hu, X. Y., Pan, X. G., Gao, W. L., Xiao, Y. M.: The reliability and accuracy of the digital models reconstructed by cone-beam computed tomography. Shanghai Kou Qiang Yi Xue., roč. 20, 2011, č. 5, s. 512-516.

12. Khambay, B., Nebel, J. C., Bowman, J., Walker, F., Hadley, D. M., Ayoub, A.: 3D stereophotogrammetic image superimposition into 3D CT scan images: the future of orthognatic surgery. Int. J. Adult Orthodon. Orthognath. Surg., roč. 17, 2002, č. 4, s. 331-341.

13. Lane, C., Harrell, W. Jr.: Completing the 3-dimensional picture. Am. J. Orthod. Dentofacial Orthop., roč. 133, 2008, č. 4, s. 612-620.

14. Ludlow, J. B., Davies-Ludlow, L. E., White, S. C.: Patient risk related to common dental radiographic examinations: the impact of 2007 International Commission on Radiological Protection recommendations regarding dose calculation. J. Am. Dent. Assoc., roč. 139, 2008, č. 9, s. 1237-1243.

15. Ludlow, J. B., Walker, C.: Assessment of phantom dosimetry and image quality of i-CAT FLX cone-beam computed tomography. Am. J. Orthod. Dentofacial Orthop., roč 144, 2013, č. 6 , s. 802-817.

16. Nadjmi, N., Mollemans, W., Daelemans, A., Van Hemelen, G., Schutyser, F., Bergé, S.: Virtual occlusion in planning orthognatic surgical procedures. Int. J. Oral Maxillofac. Surg., roč. 39, 2010, č. 5, s. 457-462.
17. Nahm, K. Y., Kim, Y., Choi, Y. S, Lee, J., Kim, S. H., Nelson, G.: Accurate registration of cone-beam computed tomography scans to 3-dimensional facial photographs Am. J. Orthod. Dentofacial Orthop., roč. 145, 2014, č. 2, s. 256-264.

18. Naudi, K. B., Benramadan, R., Brocklebank, L., Ju, X., Khambay, B., Ayoub, A.: The virtual human face: superimposing the simultaneously captured 3D photorealistic skin surface of the face on the untextured skin image of the CBCT scan. Int. J. Oral Maxillofac. Surg., roč. 42, 2013, č. 3, s. 393-400.

19. Nkenke, E., Zachow, S., Benz, M., Maier, T., Veit, K., Kramer, M., Benz, S., Häusler, G., Wilhelm- Neukam, F., Lell, M.: Fusion of computed tomography data and optical 3D images of the dentition for streak artefact correction in the simulation of orthognatic surgery Dentomaxillofacial Radiology, roč. 33, 2004, č. 4, s. 226-232.

20.Plooij, J. M., Maal, T. J., Haers, P., Borstlap, W. A., KuijpersJagtman, A. M., Bergé, S. J.: Digital three-dimensional image fusion processes for planning and evaluating orthodontics and orthognathic surgery. A systematic review. Int. J. Oral Maxillofac. Surg., roč. 40, 2011, č. 4, s. 341-352.

21. www.radiologyinfo.org

22. Rangel, F. A, Maal, T. J. J., Bronkhorst, E. M., Breuning, K. H., Schols, J. G. J. H., Berge, S. J., Kuijpers-Jagtman, A. M.: Accuracy and Reliability of a Novel Method for Fusion of Digital Dental Casts and Cone Beam Computed Tomography Scans PLOS ONE - www.plosone.org 2013; 8 (3): e59130.

23. Sajfrtová, S., Tycová, H., Foltán, R.: Možnosti předpovědi a zobrazení léčebných změn. Ortodoncie, roč. 17, 2008, č. 1, s. 36-44.

24.SEDENTEXCT - http://www.sedentexct.eu/files/guidelines_final.pdf,2008

25. Sousa, M. V., Vasconcelos, E. C., Janson, G., Garib, D., Pinzan, A.: Accuracy and reproducibility of 3-dimensional digital model measurements. Am. J. Orthod. Dentofacial Orthop., roč. 142, 2012, č. 2, s. 269-273.

26. Tarazona, B., Llamas, J. M., Cibrian, R., Gandia, J. L., Paredes, V.: A comparison between dental measurements taken from CBCT models and those taken from a digital method. Eur. J. Orthod., roč 35, 2013, č. 1, s. 1-6.

27. Ullman, V.: Radiační ochrana - http://astronuklfyzika.cz/

\section{Studie byla podporována projektem IGA MZČR} číslo 13351-4.

MDDr. Martin Šrubař

Stomatologicka klinika dětí a dospělých 2. LF UK a FN Motol $\checkmark$ Úvalu 84 15006 Praha 5 e-mail: djuji@seznam.cz
ČESKÁ OMATOLOGIE ročník 115 